


\section{Supporting teachers' use of ICT in upper secondary classrooms during and after the COVID-19 pandemic}

- Based on TALIS data collected prior to the pandemic, an average of $43 \%$ of upper secondary school teachers feel somewhat underprepared in using ICT in their teaching.

- Experienced teachers are even less comfortable with ICT. The share of upper secondary school teachers who feel comfortable with ICT is about $8 \%$ lower for teachers with more than five years of experience than for less experienced teachers.

- However, upper secondary school teachers let their students use ICT more frequently for their projects and class work - average of 60\% - than lower secondary school teachers (at 55\%).

- An average of $18 \%$ of upper secondary school teachers urgently need professional development to better integrate ICT into their teaching.

School systems around the world are making efforts to enhance and make education more efficient with information and communications technology (ICT). This has become especially urgent due to the current pandemic. Because of its rapidly evolving nature, ICT places unique demands on teachers, requiring a certain level of digital literacy and specialised pedagogical knowledge to integrate it into the classroom.

A recent OECD review of COVID-19 responses showed that out of 33 OECD countries only three educational systems remained fully open (i.e. Japan, New Zealand and Norway). Most teachers in upper secondary education had to adapt to distance or hybrid learning. Although TALIS 2018 data were collected prior to COVID-19, they give insight into challenges on this front for upper secondary education.

Using ICT effectively in teaching practices is an issue particularly worthy of attention for upper secondary teachers. Overall, TALIS 2018 data indicate that teachers feel they are not well-equipped or trained, although ICT is already a part of classroom practices. This is especially true in upper secondary schools as ICT tends to be used more often for projects or class work than in lower secondary schools. This is also evident in how many teachers reported needing professional development in this area. At the same time, ICT is one of the topics most frequently excluded from formal training.

In particular, the data suggests that more experienced teachers in upper secondary education (five years or more) struggle more with ICT than relatively new teachers (less than five years).

Teacher training in ICT usage and instruction at the collective and official level is key to a successful transition from an old to a new educational system. But efforts and careful analysis will be needed to ensure that the training actually increases teacher preparedness and meets their educational demands. It might also be worth investigating whether there are other ways to boost digital pedagogical capabilities and ICT preparedness among teachers outside of formal training. Without proper implementation, ICT use may not only be ineffective but have a negative impact on teaching and learning.

\section{What is TALIS?}

The Teaching and Learning International Survey (TALIS), established in 2008, is the first major international survey of teachers and school leaders on different aspects affecting student learning. It gives voice to teachers and school leaders, allowing them to provide input into educational policy analysis and development in key areas.

The international target population for TALIS 2018 is lower secondary teachers and their school leaders in mainstream public and private schools. For the 2018 survey, a representative sample of 4000 teachers and their school principals from 200 schools were randomly selected in each country. Across all survey components, approximately 260000 teachers responded to the survey, representing more than 8 million teachers in 48 participating countries and economies. 
TALIS participants had the opportunity to opt for a survey implementation in primary schools. Eleven countries and economies decided to engage in a TALIS survey for upper secondary education from which data is available for 10: Alberta (Canada), Brazil, Croatia, Denmark, Portugal, Slovenia, Sweden, Turkey, United Arab Emirates and Viet Nam.

Data collection took place between September and December 2017 for Southern Hemisphere participants and March to May 2018 for Northern Hemisphere participants. Since the data were collected before the COVID-19 crisis, please note that some of the frequencies and relationships among the variables reported here may have changed. More information is available at www.oecd.org/education/talis.

\section{Formal training and preparedness}

Almost half of upper secondary teachers (43\%) feel unprepared in using ICT for teaching among the TALIS countries taking part in the study. This is most pronounced in Croatia (62\%), Alberta (Canada) (57\%), Sweden (57\%) and Portugal (56\%). With regard to teachers' teaching experience and ICT use, 64\% of teachers with less than or equal to five years of experience feel comfortable with using ICT in teaching. In contrast, only $57 \%$ of teachers with more than five years of experience (Figure 1) are at ease with ICT. That is, teachers who are more experienced tend to feel less comfortable with using ICT in teaching. The percentage difference between experienced and less experienced teachers is observable in nearly all countries and exceeds 20\% in Alberta (Canada), Croatia and Portugal. This is likely because experienced teachers are older and were trained as teachers a longer time ago. Fewer experienced teachers reported that ICT teaching was part of their formal education or training (60\% compared to $72 \%$ for less experienced teachers). It is also likely that more experienced teachers did not opt for ICT-related training as much as their less experienced colleagues did.

Figure 1. Teachers' sense of preparedness in using ICT in the classroom, by levels of experience Percentage of teachers in upper secondary education who reported feeling "well" or "very well" prepared to use ICT for teaching

Percentage of teachers Less than or equal to five years of experience $\quad$ More than five years of experience

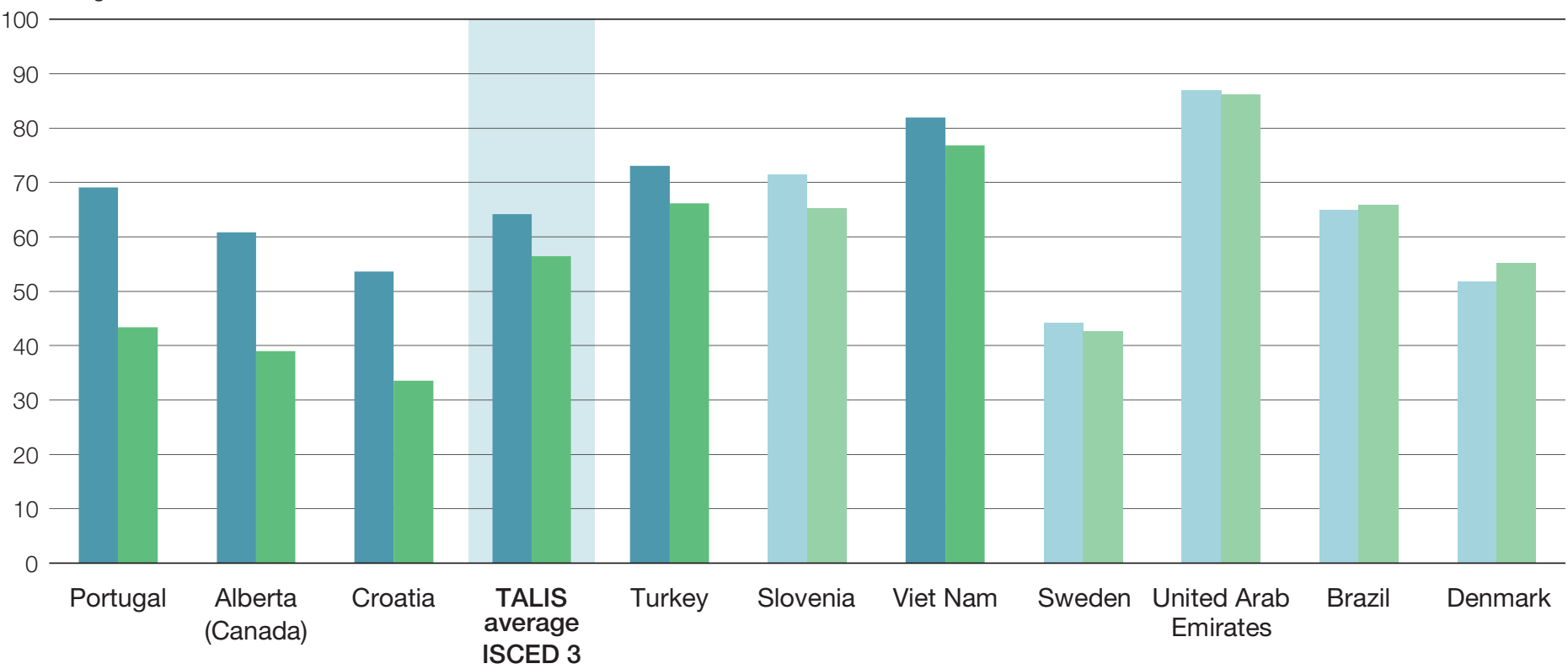

Note: Statistically significant values are marked in a darker tone.

Countries are ranked in descending order of the gap between less experienced and more experienced teachers reporting that they feel prepared in the use of ICT. Source: OECD (2019), TALIS 2018 Results Nolume I): Teachers and School Leaders as Lifelong Learners, TALIS, OECD Publishing, Paris,

https://doi.org/10.1787/1d0bc92a-en. 


\section{Use of ICT in upper secondary classrooms}

Despite many teachers' lack of ease with using ICT, it is an integral part of most classrooms. When asked what practices teachers "frequently" or "always" use in class, an average of 60\% responded that they let students use ICT for projects and class work. This was the second highest percentage after giving them tasks that require critical thinking (65\%). Moreover, this average was about 5\% higher than the average for lower secondary school teachers (55\%). With the exception of Denmark, all countries reported more frequent student use of ICT in upper secondary schools. Although ICT is used more frequently in upper secondary education, the degree of upper secondary school teachers' ICT training and preparedness is roughly the same as that of lower secondary school teachers. This indicates that more needs to be done to support teachers' ICT capacities in upper secondary school.

\section{ICT training, preparedness and needs}

Upper secondary school teachers reported a pressing need for professional development that helps them effectively integrate ICT into their teaching. On average, 18\% of teachers reported a high level of need - the highest in the survey (Figure 2).

Interestingly, a high level of need for ICT training does not correlate with teachers' levels of unpreparedness. In Croatia, less than half of teachers reported receiving training (45\%) and feeling comfortable with ICT for teaching (38\%) while also showing a relatively high share of teachers (21\%) needing training in this area. This is expected when there is not enough suitable training. Conversely, Denmark, Turkey, and the United Arab Emirates show a high share of teachers who are trained and comfortable with ICT and a low share expressing need for training. This suggests that effective training is freely available in these countries (Figure 2).

There are several other patterns. For example, Slovenia reports a relatively low share of teachers with training (44\%) but a higher share who feel prepared (66\%) as well as a low share who reported a need for professional development in this area (12\%). This implies that preparedness can be improved outside of formal training and that it would be instructive to investigate what other sources are available. In a similar vein, Alberta (Canada) reports a high share of teachers with training (71\%) but a low share who feel prepared (43\%) or need training in this area (8\%). This suggests that formal training might not always be effective. We need to be careful about mismatches between training and practical needs in the classroom (Figure 2).

Figure 2. Teachers' training, preparedness and need for use of ICT

Percentage of teachers in upper secondary reporting the following regarding the use of ICT

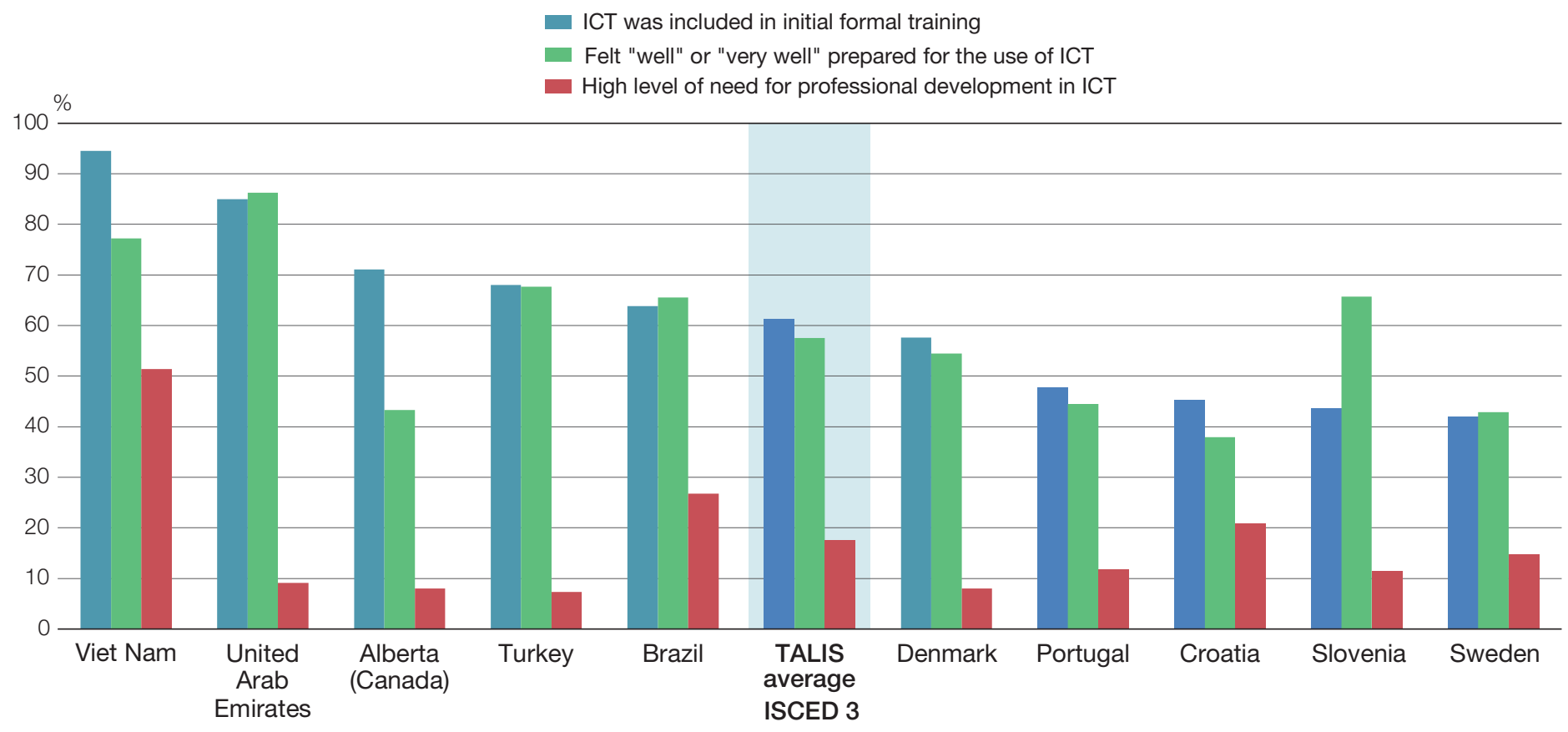

Countries and economies are ranked in descending order of the share of teachers reporting that ICT was included in their initial formal training.

Source: OECD (2019), TALIS 2018 Results Nolume l): Teachers and School Leaders as Lifelong Learners, TALIS, OECD Publishing, Paris,

https://doi.org/10.1787/1d0bc92a-en. 
Finally, Viet Nam reports the highest level of training and one of the highest levels of ICT preparedness, as well as the highest need for training. A possible explanation is that the design and implementation of in-service training actually ingrains in teachers the desire to get more training.

\section{The bottom line}

Much more needs to be done to enable upper secondary teachers to effectively integrate ICT into their teaching and classrooms. School staff have expressed that ICT professional development and digital technology are key to good education. However, simply providing more formal ICT training does not necessarily yield the desired results. The relationship between training and preparedness is complex. Further research on other elements, such as school resources and teachers' attitudes toward technology, is needed to understand how to best design ICT training. This training needs to be effective and up-to-date so that teachers can confidently apply and integrate ICT into their teaching as well as seek to continuously upgrade their pedagogical knowledge. 


\section{Contact}

Asuka Ohagi (asuka.ohagi@oecd.org) and talis@oecd.org

\section{For more information}

OECD (2019), TALIS 2018 Results (Volume I): Teachers and School Leaders as Lifelong Learners, TALIS, OECD Publishing, Paris, https://doi.org/10.1787/1d0bc92a-en.

This paper is published under the responsibility of the Secretary-General of the OECD. The opinions expressed and the arguments employed herein do not necessarily reflect the official views of OECD member countries.

This document, as well as any data and map included herein, are without prejudice to the status of or sovereignty over any territory, to the delimitation of international frontiers and boundaries and to the name of any territory, city or area.

You can copy, download or print OECD content for your own use, and you can include excerpts from OECD publications, databases and multimedia products in your own documents, presentations, blogs, websites and teaching materials, provided that suitable acknowledgment of OECD as source and copyright owner is given. All requests for commercial use and translation rights should be submitted to rights@oecd.org.

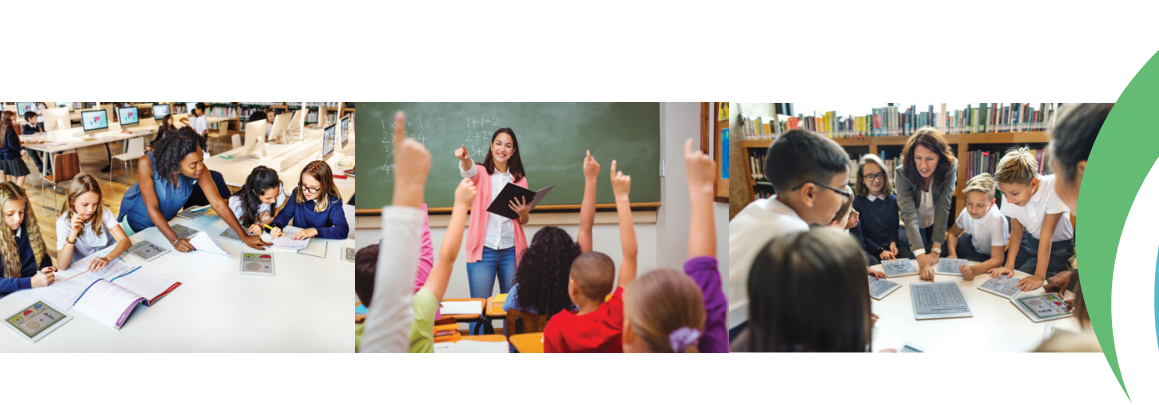

